\title{
FFAR1 wt Allele
}

National Cancer Institute

\section{Source}

National Cancer Institute. FFAR1 wt Allele. NCI Thesaurus. Code C101748.

Human FFAR1 wild-type allele is located in the vicinity of 19q13.1 and is approximately 1 $\mathrm{kb}$ in length. This allele, which encodes free fatty acid receptor 1 protein, is involved in lipid binding, receptor signaling and the regulation of insulin secretion. 